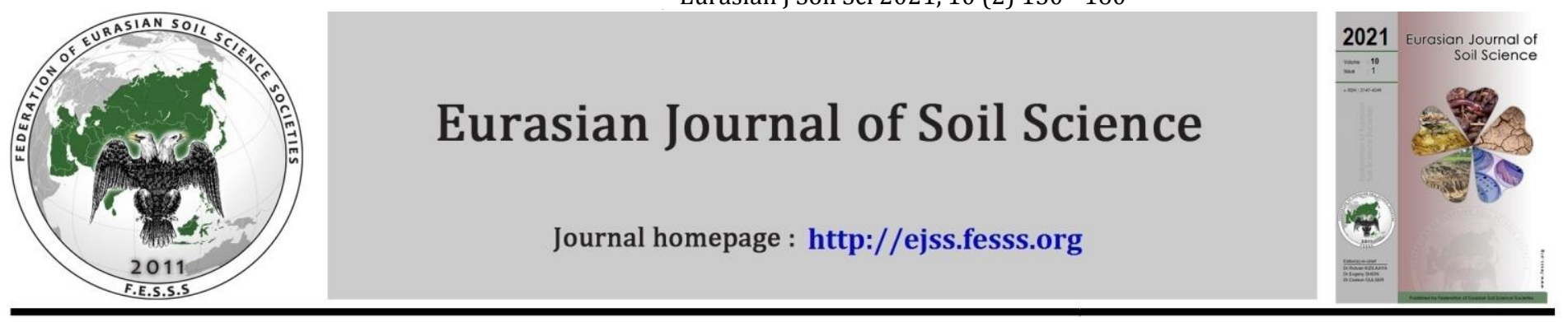

\title{
Impact of deforestation and subsequent land-use change on soil quality
}

\author{
Emmanuel Amoakwah a, Mohammad A. Rahman b, Kwabena A. Nketia a, \\ Rousseau Djouaka c, Nataliia Oleksandrivna Didenko d, Khandakar R. Islam $b$,* \\ a CSIR - Soil Research Institute, Academy Post Office, Kwadaso-Kumasi, Ghana \\ b Ohio State University South Centers, Piketon, Ohio, USA \\ ${ }^{c}$ International Institute of Tropical Agriculture, Benin \\ d Institute of Water Problems and Land Reclamation, Kyiv, Ukraine
}

\begin{abstract}
Deforestation for conventional farming has affected soil quality (SQ) worldwide. The goal of our study was to evaluate the impact of land use change, from forest to subsistence farming, on SQ in Benin. Composite soils from forest, horticultural, agricultural, fallow, and degraded lands were collected to analyze for chemical and physical properties. Using inductive additive approach and principal component analysis (PCA), generalized $\left(\mathrm{SQI}_{\mathrm{g}}\right.$ ) and minimum dataset $\mathrm{SQ}\left(\mathrm{SQI}_{\mathrm{MDS}}\right)$ indices were calculated. Results showed that upon conversion of forest, total organic carbon (TOC) decreased by more than 2 folds in fallow and degraded soils. A similar impact was observed on total nitrogen (TN). Soil cation exchange capacity (CEC) and base saturation (BS) were significantly higher under horticulture than in degraded lands. In contrast, carbon protection capacity (CPC) was significantly higher by $12-41 \%$ in forest soils compared to the lowest in degraded soils. Among the land uses, aggregate stability index (ASI) was, by far, the lowest (3.2\%) in degraded soils and highest $(7.5 \%)$ in horticulture soils. Soils under fallow and degraded lands had SQIg decreased by 5 to $16 \%$, when compared with forest, indicating a significant SQ degradation. In contrast, SQIg under horticulture increased by $5 \%$, suggesting a similar or even an improvement in SQ comparable to the forest. The PCA-based SQI IDS significantly and positively accounted for $70 \%$ of the variability in $\mathrm{SQI}_{\mathrm{g}}$ with a non-significant biasness $(6 \pm 3.8 \%$ at $\mathrm{p}<0.12)$. The TOC and CPC contributed most $(20.9 \%$ and $21.1 \%)$ followed by clay $(14.1 \%)$ and $\mathrm{Ca}^{+2}:\left(\mathrm{Mg}^{+2}+\mathrm{K}^{+1}+\mathrm{Na}^{+}\right)(13.7 \%)$, TOC $(11 \%)$, and ASI $(10.5 \%)$ compared to lowest by $\mathrm{K}^{+}(9.7 \%)$ to account for $\mathrm{SQI}_{\mathrm{MDS}}$ variability. Our results concluded that there was no significant difference between $\mathrm{SQI}_{\mathrm{g}}$ and $\mathrm{SQI} \mathrm{I}_{\mathrm{MDS}}$, which justified our results to use $\mathrm{SQI} \mathrm{I}_{\mathrm{MDS}}$ detecting management-induced changes in SQ.
\end{abstract}

\section{Article Info}

Received : 11.06 .2020

Accepted : 19.11.2020

Keywords: Soil degradation, slush-burn agriculture, Carbon protection capacity, minimum dataset, Soil quality.

(C) 2021 Federation of Eurasian Soil Science Societies. All rights reserved

\section{Introduction}

Developing and improving soil quality (SQ) is urgently needed to support global food security. Managementinduced temporal changes in SQ attributes and its processes, in turn, can affect soil functions to influence plant growth and food production; therefore, understanding and evaluating the impact of land use change on SQ is critical to enhance ecosystem services (Tellen and Yerima, 2018; Nguemezi et al., 2020). In Africa, SQ has been degrading rapidly due to subsistence farming by an ever-rising population, this is a critical issue in

\section{E.Amoakwah M.A. Rahman \\ K.A. Nketia \\ R. Djouaka \\ N.O. Didenko \\ * K.R. Islam}

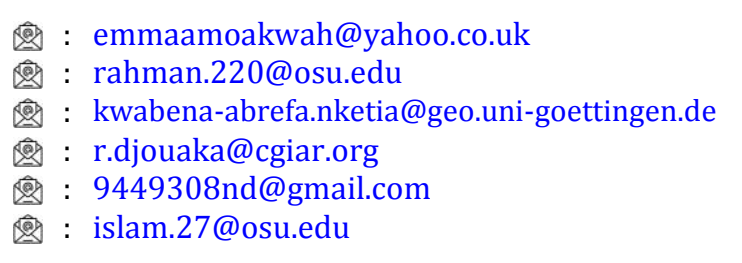

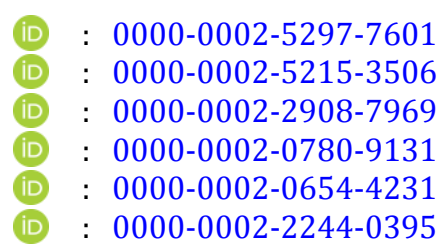

(Corresponding author) 
Africa that is adversely impacting agriculture and food security (Moebius-Clune et al., 2011; Alarima et al., 2020). It is reported that subsistence farming, is often associated with poor SQ, leading to a decline in agricultural productivity (Obalum et al., 2012).

In Benin, as one of the small Sub-Saharan West African countries, the impact of subsistence farming on SQ is a major growing agronomic and environmental concern. Due to rapid population growth, large areas under primary natural forest were deforested and subsequently converted into conventional agriculture and other anthropogenic activities (Ouedraogo et al., 2010). Increasing population growth, particularly in southern Benin, has led to the degradation of natural forest and shrubby fallows due to subsistence farming, resulting in accumulation of marginal lands (Félix et al., 2015). The assessment of soil degradation in Benin showed negative balances and consequently, the performance of agricultural production was reduced by 62\% (Félix et al., 2015). Due to lack of available alternative technologies and knowledge, small-scale farmers are overexploiting natural resources and consequently, affected soil's functional capacity.

Agricultural land use in Benin depends largely on topographic position, as rain fed subsistence cropping is less intensified in the foothills of the valleys compared to the fringes and uplands (Prasad and Nolte, 1995). While about $35 \%$ of the area in the foothills of the valleys is under cultivation, $74 \%$ of the area is under cultivation on the fringes, and $30 \%$ of the area is under cultivation on the uplands. However, agriculture in Benin remains vulnerable due to the use of low yield crop varieties, lack of inputs, and subsistence farming practices that are not adapted to climate change impacts.

To maintain soil productivity, chemical fertilizers and animal manures are applied to agronomic crops, homestead gardens, and other production areas (Sangare et al., 2012; Perrin et al., 2015). In recent years, the orchard growers (such as pineapples) in southern Benin have started to apply unconventional sources of nutrients and soil amendments, such as biosolids and greywater, to enhance SQ to support for economic crop production (Kpera et al., 2019).

Evaluation of SQ is commonly performed using laboratory analysis of antecedent soil physical, chemical, and biological properties in response to management practices (Marzaioli et al., 2010; Aziz et al., 2013; Davari et al., 2020). There is an urgent need to assess the impact of on-going land-use change, upon deforestation and conversion of forest, on SQ in Benin. Moreover, climate change is not just a threat to terrestrial ecosystems in the distant future; it is already affecting African agroecosystems, including Benin (Sintayehu, 2018).

The most common and effective strategy for adapting to deforestation and climate change is to develop sustainable agricultural practices to maintain and develop SQ. However, there is a lack of information on the effects of deforestation and conversion of land on SQ in Benin. The objective of our study was to evaluate the impact of diverse land use changes on soil chemical and physical properties, and their contribution to mathematical- and statistical model based SQ evaluation in southern Benin.

\section{Material and Methods}

\section{Study area and soil sampling}

The study was conducted in the vicinity of the Ze region of southern Benin, West Africa. While the highest precipitation (1200 to $1300 \mathrm{~mm}$ ) is confined to the southern region, the lowest values are recorded in the northern region (900 to $950 \mathrm{~mm}$ ) of Benin. Mean annual air temperatures range from $26-28^{\circ} \mathrm{C}$ and occasionally reach $35-40^{\circ} \mathrm{C}$ in northern localities.

Ferrallitic-ferruginous soil (Ferrasols and Acrisols according to the USDA and FAO classification, respectively) with a dominant sandy loam-loamy sand texture. Geo-referenced composite soils (0 to $15 \mathrm{~cm}$ depth) were collected from (1) Forest $(\mathrm{n}=18)$ that consists of Pawpaw (Asimina triloba), teak (Tectona grandis), and palm (Elaies guinenses); (2) Horticulture $(\mathrm{n}=36)$ that consists of lands under banana (Musa $\times$ paradisiaca), pineapple (Ananas comosus), and tomato (Solanum lycopersicum); (3) Agriculture $(\mathrm{n}=24)$ that consists of lands under cassava (Manihot esculenta), yams (Dioscorea spp.), green beans (Phaseolus vulgaris), maize (Zea mays), and cotton (Gossypium spp.); (4) Fallow ( $\mathrm{n}=42)$; and (5) Degraded ( $\mathrm{n}=18)$ what consists of lands under the dominance of elephant grass (Imperata cylindrica).

\section{Soil management and cultural practices}

Soil management and cultural practices differed among land uses. While the routine application of liming materials and chemical fertilizers by small-scale farmers is economically unfeasible, soils under small-scale both horticultural and agricultural crops were seasonally amended with household ashes, animal manures, composts, and other unconventional organic sources as a neutralizer of soil acidity and supplier of nutrients for tropical acid soils. Annual household animal manuring of soil generally in between 4 to 10 ton ha-1, on a wet weight basis. However, liming and chemical fertilizations were performed occasionally more for agricultural crops than for horticultural crops. Liming @ 0.5 to 2 ton ha-1 was applied to the field with along 
with N, P, and K fertilization 30-50, 25-45, and 120-45 $\mathrm{kg} \mathrm{ha}^{-1}$. The horticultural crops were occasionally irrigated manually. Standard cultural practices associated with planting and harvesting of crops were performed.

\section{Soil processing and analysis}

The field-moist soils were collected in sealable plastic bags, then gently sieved through 4-mm mesh to remove stones, roots, and large organic residues, air-dried under shade at room temperature $\left(\sim 25^{\circ} \mathrm{C}\right)$ for a period of 15-days, grinded with porcelain mortar and pestle, and finally passed thru a 2-mm sieve before analysis.

Soil pH was determined in distilled water at a soil: water ratio of 1:2.5 using a pH glass electrode. Total organic C (TOC) content was determined by the modified Walkley-Black wet digestion method (Jackson, 1958). Total N (TN) was determined by microkjeldahl digestion and distillation method. The available P (AP) was measured by following the Bray- 1 method after extracting the soil with a $0.3 \mathrm{M} \mathrm{NH} \mathrm{N}_{4} \mathrm{~F}$ in $0.5 \mathrm{M}$ HC1 mixture followed by spectrophotometric determination by the ascorbic acid method (Murphy and Riley, 1962).

Soil cation exchange capacity (CEC) was determined by $\mathrm{NH}_{4}$-acetate extraction and stem distillation method (Rhoades, 1982). The exchangeable cations were extracted with a $1 \mathrm{M}$ neutral $\mathrm{NH}_{4}$-acetate solution and were determined by atomic absorption spectrophotometry. Using the exchangeable cations data, the $\mathrm{Ca}^{2+}: \mathrm{Mg}^{2+}$ and $\mathrm{Ca}^{2+}:\left(\mathrm{Mg}^{2+}+\mathrm{K}^{2+}+\mathrm{Na}^{+}\right)$, as measures of soil balancing and dispersion, were calculated (Schulte and Kelling, 1993). Aggregate stability index (ASI) relating soil resistance to external disruption forces was assessed using Pieri (1992). Soil particle size analysis (sand, silt, and clay contents) was determined by the standard Bouyoucos hydrometer method. While total surface area of soil was calculated by following Thein and Graveel (1997), the carbon protection capacity (CPC) was calculated by following Hassink (1997).

\section{Derivation and calibration of soil quality}

A modified inductive additive approach (Huddleston, 1984; Wymore, 1993; Aziz et al., 2013) was followed to calculate for SQ. First, a generalized SQ index (SQI $)_{g}$ was calculated by accounting the status or concentration of all measured or calculated soil properties' potential SQ indicators under agriculture, horticulture, fallow, and degraded lands considering those were once the same as that of the soils under the adjacent natural forests prior to conversion.

Data were normalized considering assumptions "higher values of soil properties are better indicators of SQ" in response to management practices (Wymore, 1993; Aziz et al., 2013). Datum (x) of each individual soil property was normalized $\left(\mathrm{x}_{\mathrm{i}}\right)$ relative to the maximum value $\left(\mathrm{x}_{\max }\right)$ of that particular property to transform into $\geq 0$ to 100 based on linear scoring functions, $x_{i}=\left(x \times x_{\max ^{-1}}\right)$. By summing all the $x_{i}^{\prime} s$ and dividing by the number of $\mathrm{x}_{\mathrm{i}}^{\prime} \mathrm{s}(\mathrm{n})$, the $\mathrm{SQI}_{\mathrm{g}}$ was calculated:

$$
\mathrm{SQI}_{\mathrm{g}}=\Sigma\left(\mathrm{x}_{\mathrm{i}}+\ldots . .+\mathrm{x}_{\mathrm{n}}\right) \mathrm{n}^{-1}
$$

The calculated SQI $I_{g}$ ranged from $\geq 0$ to 100 , with 100 being excellent soil quality and $>0$ being extremely poor soil quality. Data were normalized to convert for removing variable units into a unit-less format, reducing heterogeneous variances of the errors, and simplifying the relationship between random errors influencing the SQ properties.

To avoid any biasness and data redundancy in $\mathrm{SQI}_{\mathrm{g}}$, a minimum dataset (MDS) of orthogonal soil properties was selected using Principle Component Analysis (PCA) to derive for SQI $I_{M D S}$ (Chandel et al., 2018). All the original untransformed data of each soil property were included in the PCA model using Origin Pro 2018. Under a given PC, each variable had corresponding eigenvector weight value or factor loading. The PCs that had eigen value $>1.0$ and explained at least $5 \%$ of the variation in the data were selected (Rezaei et al., 2006). When more than one factor was retained under one PC, the multivariate correlation was performed to select orthogonal soil attributes for calculating the $\mathrm{SQI}_{\mathrm{MDS}}$. To calibrate, the SQI was then regressed on the SQI $\mathrm{I}_{\mathrm{MDS}}$ for accounting significant variations in $\mathrm{SQI}_{\mathrm{g}}$ as explained by the PCA selected $\mathrm{SQI} \mathrm{IDS}_{\mathrm{MD}}$.

\section{Statistical analysis}

One-way analysis of variance procedure of the SAS 9.3 was used to evaluate the effects of land use on soil properties and SQ indices. The Least Significant Difference (LSD) test was used to separate the means of the dependent variables in response to predictor variables at $p \leq 0.05$ unless otherwise mentioned. Averaged across all the data, a separate one-way ANOVA was performed to test whether the SQIg and SQIMDS comparisons produced similar differences in all the dataset. SigmaPlot ${ }^{\circledR}$ was used for regression and correlation analyses. 


\section{Results and Discussion}

\section{Impact of land-use changes on soil properties}

Soil pH varied significantly by the impact of land-use changes upon conversion of forest (Table 1), with lowest pH (5.7) in degraded soils and highest pH (7.1) in horticultural soils. Upon conversion of forest, TOC content decreased by 1.6 to 2.7 folds in soils under agriculture and degraded lands. Soils under horticulture and fallow had more than 2 folds less TOC than in soils under forest. A similar impact was observed on TN content. The AP availability was low, with highest AP content in horticultural and agriculture soils relative to forest and degraded soils. While a significantly higher Ca content was measured in both horticultural and agricultural soils than in degraded, fallow, and forest soils (Table 2), $\mathrm{K}^{+}$content was higher in horticultural soils in soils under other land use systems. Soils under agriculture and horticulture had significantly higher $\mathrm{Ca}^{2+}: \mathrm{Mg}^{2+}$ and $\mathrm{Ca}^{2+}:\left(\mathrm{Mg}^{2+}+\mathrm{K}^{+}+\mathrm{Na}^{+}\right)$and degraded soils had the lowest $\mathrm{Ca}^{2+}: \mathrm{Mg}^{2+}$ and $\mathrm{Ca}^{2+}$ : $\left(\mathrm{Mg}^{2+}+\mathrm{K}^{+}+\mathrm{Na}^{+}\right)$values.

Table 1. Impact of land-use change on soil $\mathrm{pH}$, total organic carbon, total nitrogen, and available phosphorus upon conversion of primary natural forest in Southern Benin.

\begin{tabular}{lccccc}
\hline Land-use/ Land covers & $\mathrm{pHw}(1: 2.5)$ & $\mathrm{TOC}\left(\mathrm{g} \mathrm{kg}^{-1}\right)$ & $\mathrm{TN}\left(\mathrm{g} \mathrm{kg}^{-1}\right)$ & $\mathrm{CN} \mathrm{ratio}$ & $\mathrm{AP}\left(\mathrm{mg} \mathrm{kg}^{-1}\right)$ \\
\hline Forest (control) & $6.6^{\mathrm{b}}$ & $9.3^{\mathrm{a}}$ & $0.85^{\mathrm{a}}$ & $11.0^{\mathrm{a}}$ & $4^{\mathrm{c}}$ \\
Horticulture & $7.1^{\mathrm{a}}$ & $7.1^{\mathrm{b}}$ & $0.61^{\mathrm{b}}$ & $12.4^{\mathrm{a}}$ & $10^{\mathrm{a}}$ \\
Agriculture & $6.8^{\mathrm{ab}}$ & $5.7^{\mathrm{b}}$ & $0.49^{\mathrm{b}}$ & $11.8^{\mathrm{a}}$ & $8^{\mathrm{ab}}$ \\
Fallow & $6.8^{\mathrm{ab}}$ & $7.0^{\mathrm{b}}$ & $0.61^{\mathrm{b}}$ & $11.3^{\mathrm{a}}$ & $6^{\mathrm{bc}}$ \\
Degraded & $5.7^{\mathrm{c}}$ & $3.5^{\mathrm{c}}$ & $0.28^{\mathrm{c}}$ & $12.5^{\mathrm{a}}$ & $4^{\mathrm{c}}$ \\
\hline
\end{tabular}

$¥$ Means separated by same lower-case letter under each column were not significantly different at $\mathrm{p} \leq 0.05$ among land uses.

Table 2. Impact of land-use change on soil exchangeable calcium, magnesium, potassium, and sodium contents, cation exchange capacity, and base saturation upon conversion of primary natural forest in southern Benin.

\begin{tabular}{|c|c|c|c|c|c|c|c|c|}
\hline \multirow{2}{*}{$\begin{array}{l}\text { Land-use/ } \\
\text { Land covers }\end{array}$} & $\mathrm{Ca}^{2+}$ & $\mathrm{Mg}^{2+}$ & $\mathrm{K}^{+}$ & $\mathrm{Na}^{+}$ & \multirow{2}{*}{$\mathrm{Ca}^{2+}: \mathrm{Mg}^{2+}$} & \multirow{2}{*}{$\mathrm{Ca}^{2+}:\left(\mathrm{Mg}^{2+} \mathrm{K}^{+} \mathrm{Na}^{+}\right)$} & \multirow{2}{*}{$\begin{array}{c}\text { CEC } \\
(\mathrm{cmol} / \mathrm{kg})\end{array}$} & \multirow{2}{*}{$\begin{array}{c}\mathrm{BS} \\
(\%) \\
\end{array}$} \\
\hline & \multicolumn{4}{|c|}{$(\mathrm{mg} / \mathrm{kg})$} & & & & \\
\hline Forest (control) & $126^{b ¥}$ & $20^{a}$ & $20^{b}$ & $2^{a}$ & $3.8^{b}$ & $2.8^{b c}$ & $3.8^{b}$ & $33.9^{b}$ \\
\hline Horticulture & $220^{a}$ & $23^{a}$ & $37^{a}$ & $4^{\mathrm{a}}$ & $5.6^{\mathrm{a}}$ & $3.6^{a b}$ & $4.7^{\mathrm{a}}$ & $44.7^{\mathrm{a}}$ \\
\hline Agriculture & $199^{a}$ & $17^{\mathrm{a}}$ & $18^{b}$ & $2^{a}$ & $6.9^{a}$ & $4.9^{a}$ & $3.8^{b}$ & $46.7^{\mathrm{a}}$ \\
\hline Fallow & $110^{b}$ & $20^{a}$ & $24^{b}$ & $3^{a}$ & $3.4^{b}$ & $2.3^{b c}$ & $3.6^{b}$ & $33.3^{b}$ \\
\hline Degraded & $69^{c}$ & $20^{a}$ & $16^{b}$ & $2^{\mathrm{a}}$ & $2^{c}$ & $1.6^{\mathrm{c}}$ & $4.2^{\mathrm{ab}}$ & $20.2^{\mathrm{c}}$ \\
\hline
\end{tabular}

¥Means separated by same lower-case letter under each column were not significantly different at $\mathrm{p} \leq 0.05$ among land uses.

Similarly, CEC was significantly higher by 19 to $24 \%$ in soils under horticulture compared to lowest in degraded soils. Soils under both agriculture and horticulture had the highest base saturation (BS) as compared lowest in fallow and degraded soils. Highest values of TOC: $\mathrm{Ca}^{2+}$ were measured in soils under forest followed by fallow and degraded soils when compared with soils under horticulture and agriculture, respectively (Table 3). The TOC: clay was highest in soils under forest compared to lowest in degraded soils. Similarly, the CPC was significantly higher by 12 to $41 \%$ in forest soils followed by agriculture, horticulture, and fallow soils compared to the lowest in degraded soils. The silt content was significantly lower in degraded soils when compared with forest (Table 3). Even soils under horticulture, agriculture, and fallow had lower silt content than in forest soils. In contrast, soils under horticulture had the highest surface area $\left(18.8 \mathrm{~m}^{2} \mathrm{~g}^{-1}\right)$ relative to lowest surface area $\left(14 \mathrm{~m}^{2} \mathrm{~g}^{-1}\right)$ in agriculture soils (Table 3$)$. The impact of land-use change on ASI with conversion of primary natural forest showed that the ASI was, by far, the lowest (3.2\%) in degraded soils and highest (7.5\%) in horticulture soils (Figure 1). Likewise, soils under forest and agriculture had higher ASI values than the degraded soils. Even the fallow soils had higher ASI (6\%) than the degraded soils.

Table 3. Impact of land-use change on sand, silt and clay, carbon protection capacity, and surface area in soils upon conversion of primary natural forest in southern Benin.

\begin{tabular}{|c|c|c|c|c|c|c|c|}
\hline \multirow{2}{*}{$\begin{array}{l}\text { Land-use/ } \\
\text { Land covers }\end{array}$} & Sand & Clay & Silt & \multirow{2}{*}{$\begin{array}{c}\text { Surface area } \\
\left(\mathrm{m}^{2} \mathrm{~g}^{-1}\right)\end{array}$} & \multirow{2}{*}{ TOC: $\mathrm{Ca}$} & \multirow{2}{*}{ TOC: Clay } & \multirow{2}{*}{$\begin{array}{c}\mathrm{CPC} \\
\left(\mathrm{g} \mathrm{kg}^{-1}\right)\end{array}$} \\
\hline & & $(\%)$ & & & & & \\
\hline Forest (control) & 126 b¥ & $20^{a}$ & $20^{b}$ & $2^{a}$ & $3.8^{b}$ & $2.8 \mathrm{bc}$ & $3.8^{b}$ \\
\hline Horticulture & $220^{a}$ & $23^{a}$ & $37^{a}$ & $4^{a}$ & $5.6^{\mathrm{a}}$ & $3.6^{\mathrm{ab}}$ & $4.7^{\mathrm{a}}$ \\
\hline Agriculture & $199^{a}$ & $17^{\mathrm{a}}$ & $18^{b}$ & $2^{a}$ & $6.9^{a}$ & $4.9^{\mathrm{a}}$ & $3.8^{b}$ \\
\hline Fallow & $110^{b}$ & $20^{a}$ & $24^{b}$ & $3^{a}$ & $3.4^{b}$ & $2.3 \mathrm{bc}$ & $3.6^{b}$ \\
\hline Degraded & $69^{c}$ & $20^{a}$ & $16^{b}$ & $2^{a}$ & $2.0^{c}$ & $1.6^{\mathrm{c}}$ & $4.2^{\mathrm{ab}}$ \\
\hline
\end{tabular}

${ }^{¥}$ Means separated by same lower-case letter under each column were not significantly different at $\mathrm{p} \leq 0.05$ among land uses. 


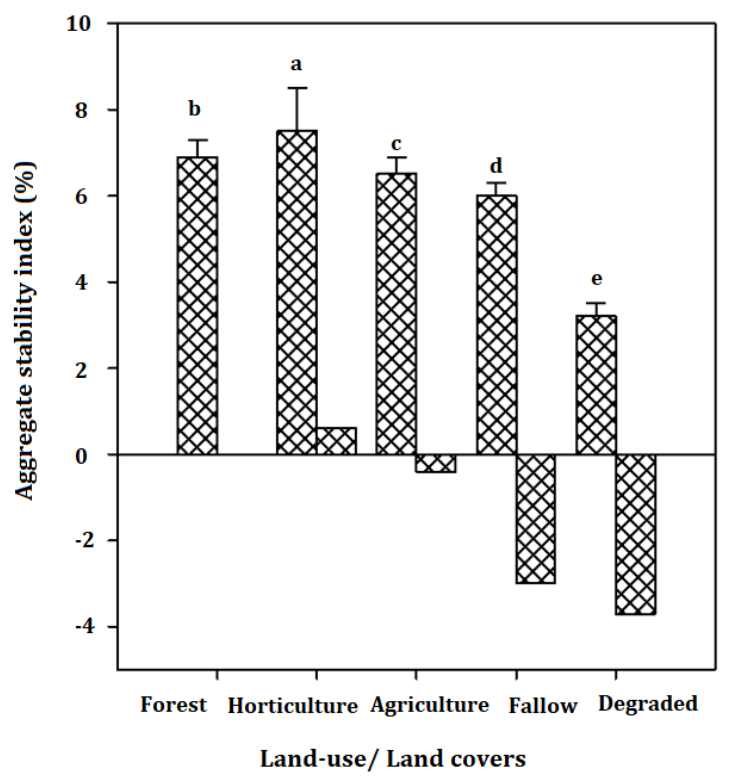

Figure 1. Impact of land-use change on soil aggregate stability index (ASI) upon conversion of primary natural forest in Southern Benin (The upward and downward second bar represented the increased and decreased ASI in comparison with forest, respectively).

Significantly lowest $\mathrm{pH}$ in degraded soils was due to the consequences of the leaching of basic cations and dominance of exchangeable $\mathrm{H}^{+}$and $\mathrm{Al}^{+3}$ compared to other soils (Neina, 2019). Accelerated leaching of basic cations ( $\mathrm{Ca}, \mathrm{Mg}, \mathrm{K}$, etc.) due to high rainfall and erosion was also responsible for causing acidity in degraded soils. A greater demand for, and uptake, of basic cations by forest vegetation over time was responsible for the more acidic nature of soils than horticulture, agriculture, and fallow soils.

In contrast, biomass ash amended from traditional slush-burn practices on horticulture, agriculture, and fallow soils could have recycled basic cations to maintain or increase $\mathrm{pH}$, at least temporarily (Voundi Nkana et al., 1998). Moreover, liming of intensively managed horticultural and agricultural fields is likely one of the contributing factors for slightly higher $\mathrm{pH}$ relative to low $\mathrm{pH}$ values in degraded soils. Greater biomass additions to the soil surface through leaf fall under forest might have contributed to higher TOC contents.

A reduced contact between surface accumulated high $\mathrm{C}$ : $\mathrm{N}$ litter-fall and microbial diversity favored slower decomposition of residues with a higher anabolism under physically undisturbed forest ecosystems (Islam and Weil 2000a; Adaikwu et al., 2012). In contrast, the lower levels of TOC in degraded soils may have resulted over time from a combination of several factors, such as lower C inputs because of sparse vegetation and less biomass return, slush-burn practices, accelerated soil erosion, rapid decomposition due to high relative humidity and temperatures, and uncontrolled livestock grazing (Mullar-Harvey et al., 1985). Likewise, a relatively lower TOC content in soils under horticulture and agriculture than in forest soils could be due to the reduced amount of crop residues being returned to the soil, higher rates of soil organic matter (SOM) oxidation as a result of frequent plowing and slush-burn practices, and removal of harvested green leafy materials (Moges and Holden, 2008; Yimer et al., 2007). In addition, frequent plowing may have accelerated the breakdown of soil aggregates and exposure of aggregate protected carbon to microbial oxidation by changing the $\mathrm{O}_{2}$ diffusion, moisture, and temperature regimes (Reicosky and Forcella, 1998).

As N is stoichiometrically linked with C in SOM (Kirkby et al., 2013), a greater TN content in forest soils than in horticultural and agricultural soils was probably due to higher litter input, C: $\mathrm{N}$ stoichiometry, and biological $\mathrm{N}$ fixation by the naturally grown leguminous vegetation (Moges et al., 2013). In contrary, a lower amount of TN in soils under horticulture and agriculture was due to removal of $\mathrm{N}$-enriched leafy biomass and grains during harvest and insufficient replenishment of $\mathrm{N}$ through manure or chemical fertilizers. The lowest TN content in degraded soils was due to C:N stoichiometry, soil erosion, and lack of continuity of $\mathrm{N}$ fertilization. Likewise, a significantly lower amount of AP in degraded soils was likely associated with lack of P fertilization and higher P fixation by ferruginous minerals (Yimer et al., 2007; Koda et al., 2018). While P fixation is a problem in Ferrallitic-ferruginous soils, the higher TOC content in horticulture soils might have decreased P fixation and increased AP (Moges et al., 2013; Kalu et al., 2015). Moreover, a relatively higher AP content in soils under horticultural might be due to biomass ash application, manure amendments, and $\mathrm{P}$ fertilization to support growing crops and vegetables. 
A higher content of $\mathrm{Ca}^{2+}$ and $\mathrm{K}^{+}$in soils under horticulture was probably due to the application of household biomass ashes, liming, and fertilization, as biomass ash is a good source of calcium, potassium, phosphorous and magnesium (Voundi Nkana et al., 1998). Moreover, diverse vegetative cover reportedly increased the recycling of $\mathrm{Ca}$ contents in soil (Moges et al., 2013). The increased availability of $\mathrm{K}^{+}$in soils under horticulture might also have resulted from reduced $\mathrm{K}^{+}$fixation and a release of $\mathrm{K}^{+}$due to the interaction of TOC with clay minerals (Sharma et al., 2001). The $\mathrm{Ca}^{2+}:\left(\mathrm{Mg}^{2+}+\mathrm{K}^{+}+\mathrm{Na}^{+}\right)$, as measures of soil's resistance to aggregate dispersion in response to rainfall impacts, erosion, and flooding, was higher in soils under horticulture and agriculture. This may be associated with the application of household biomass ashes, liming, and recycling of basic cations from the subsoil by the vegetation and returning them into the topsoil (Yimer et al., 2007).

The BS, as an indicator of the cationic fertility status of soil (Chesworth, 2008), was significantly higher under agriculture and horticulture compared to forest, in response to manure and biomass ash amendments, liming, and chemical fertilization. Biomass ash from traditional slush-burn practices, lime, and unconventional sources of fertilization (Kpera et al., 2019) could have recycled basic cations to maintain and/or improve both CEC and BS in soils under horticulture and agriculture. On the contrary, the lower CEC and BS were related to the low SOM and nutrient content, erosion, and lack of chemical fertilization and liming. A greater recycling of $\mathrm{Ca}^{2+}$ showed higher $\mathrm{Ca}^{2+}: \mathrm{Mg}^{2+}$ and $\mathrm{Ca}^{2+}:\left(\mathrm{Mg}^{2+}+\mathrm{K}^{+}+\mathrm{Na}^{+}\right)$values in soils under horticulture and agriculture compared to degraded soils. However, both $\mathrm{Ca}^{2+}: \mathrm{Mg}^{2+}$ and $\mathrm{Ca}^{2+}$ : $\left(\mathrm{Mg}^{2+}+\mathrm{K}^{+}+\mathrm{Na}^{+}\right)$values in all soils were below the critical limits of a balanced soil. In contrast, a relative shortage of $\mathrm{Ca}, \mathrm{CEC}$, and BS in degraded soils was readily reflected in the lower $\mathrm{Ca}^{2+}:\left(\mathrm{Mg}^{2+}+\mathrm{K}^{+}+\mathrm{Na}^{+}\right)$levels as an indicator of degraded and unbalanced soils.

A considerably lower silt content soil, especially in degraded soils than in forest soils, was most likely because of preferential removal of silt by soil erosion. In contrast, degraded soils with lower values of surface area reflected in the lower values of CPC. A greater amount of TOC with improved aggregate stability in forest soils might have developed more CPC than in horticultural, agricultural, fallow, and degraded soils because physical disturbance periodically breaks down macroaggregates and exposes aggregate protected $\mathrm{C}$ (e.g. particulate organic matter) and accelerates SOM decomposition by opportunistic microbes (Islam and Weil, 2000b). The soils under horticulture had higher ASI than agriculture, which suggested that soils under horticulture had improved fertility more than the soils under agriculture (Zhang et al., 2016). The difference of ASI between horticulture and agriculture was probably associated with variable TOC contents, which influenced the API (Onweremadu et al., 2007; Durigan et al., 2017). In addition, both horticulture and agriculture soils might have created conditions for the accumulation of SOM, thereby causing improved ASI (Nimmo et. al., 2002). It is reported that a decrease in ASI leads to the degradation of macroaggregates, dispersion of finer soil particles, and sealing of pores with dispersed finer particles (Schwartz et al., 2003; Ezeaku, 2015).

\section{Impact of land-use change on soil quality}

The SQI $\mathrm{I}_{\mathrm{g}}$ calculated by including all the data, reflected an overall status of the integrated soil properties by the impact of land-use changes (Figure 2). The fallow and degraded soils had lower SQ by 5 and $16 \%$, respectively, indicating a significant SQ degradation over time when compared with the forest. The values of SQ of degraded lands were also significantly lower by 9 to $11 \%$ than that of agriculture and fallow lands. On the contrary, the SQ under horticulture was significantly higher by $5 \%$, suggesting a similar or even an improvement in SQ compared to forest. Islam and Weil (2000a) reported similar results upon the conversion of forests for conventional agriculture.

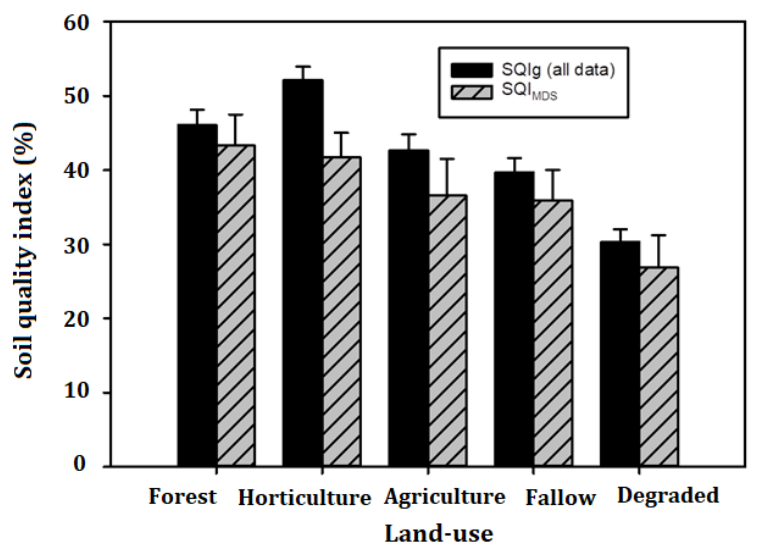


Figure 2. Impact of land-use change on generalized (SQIg) and minimum dataset (SQIMDS) based soil quality indices upon conversion of primary natural forest in Southern Benin.

The use of PCA to identify weighted soil attributes showed dissimilarities within land use systems (Figure 3). Thus, the $\mathrm{Ca}^{2+}: \mathrm{Mg}^{2+}, \mathrm{Ca}^{2+}:\left(\mathrm{Mg}^{2+}+\mathrm{K}^{+}+\mathrm{Na}^{+}\right)$and BS for PC-1, the K, Na and TOC: clay for PC-2, the CPC for PC3 , the ASI for PC-4, and the clay for PC-5 were identified based on highly weighted eigenvectors, therefore those were selected to further calculate for $\mathrm{SQI}_{\mathrm{MDS}}$ and calibrate with SQI $\mathrm{I}_{\mathrm{g}}$ to evaluate its applicability.

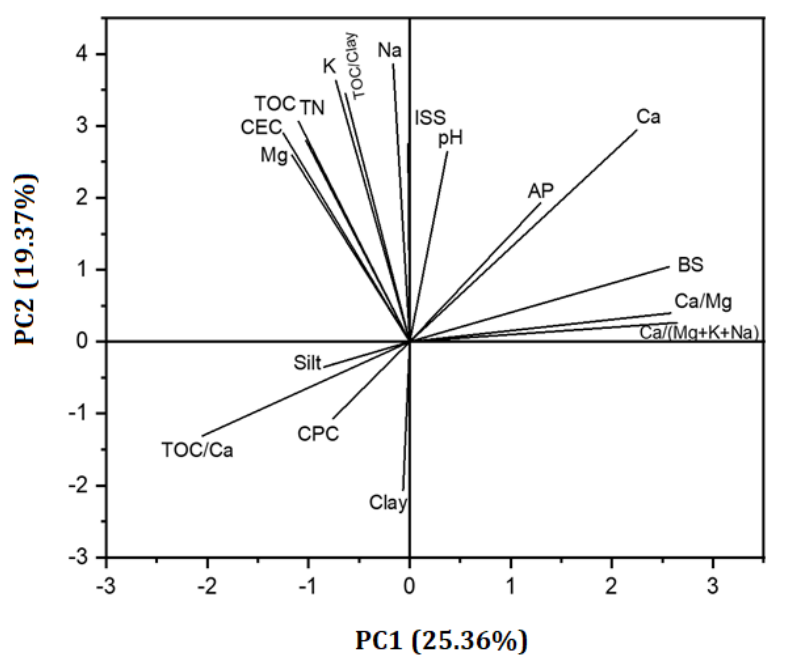

Figure 3. Impact of land-use change on distribution of weighted variables using principal component analysis.

The highly weighted attributes of $\mathrm{PC}-1$, the $\mathrm{Ca}^{2+}: \mathrm{Mg}^{2+}$, and $\mathrm{Ca}^{2+}:\left(\mathrm{Mg}^{2+}+\mathrm{K}^{+}+\mathrm{Na}^{+}\right)$were significantly correlated with each other (Table 4), thereby the $\mathrm{Ca}^{2+}:\left(\mathrm{Mg}^{2+}+\mathrm{K}^{+}+\mathrm{Na}^{+}\right)$with the highest factor loading

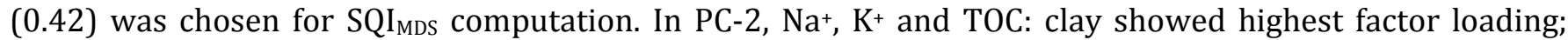
however, Na showed a significant correlation with $\mathrm{K}^{+}$, thus, only $\mathrm{K}^{+}$and TOC: clay were included because $\mathrm{K}^{+}$ $(0.35)$ is one of the important attributes in African soil. The CPC (0.49) was the only attribute chosen from PC-3.

Table 4. Principal component analysis to select attributes for calculation of soil quality index based on minimum datasets $\left(\mathrm{SQI}_{\mathrm{MDS}}\right)$ under diverse land-use systems.

\begin{tabular}{|c|c|c|c|c|c|}
\hline \multirow{2}{*}{ Soil attributes } & \multicolumn{5}{|c|}{ Components } \\
\hline & PC-1 & PC-2 & PC-3 & PC-4 & PC-5 \\
\hline $\mathrm{pH}$ & 0.06 & 0.25 & -0.17 & 0.18 & -0.08 \\
\hline TOC & -0.17 & 0.27 & 0.37 & -0.20 & 0.16 \\
\hline TN & -0.18 & 0.29 & 0.35 & -0.20 & 0.15 \\
\hline $\mathrm{Ca}$ & 0.36 & 0.28 & 0.12 & 0.05 & 0.01 \\
\hline Mg & -0.19 & 0.25 & -0.21 & 0.26 & 0.11 \\
\hline Ca: Mg & 0.42 & 0.04 & 0.19 & -0.05 & -0.02 \\
\hline $\mathrm{K}$ & -0.12 & 0.35 & -0.02 & 0.25 & 0.20 \\
\hline Ca: $\left(\mathrm{Mg}^{2+}+\mathrm{K}^{+}+\mathrm{Na}^{+}\right)$ & 0.43 & 0.03 & 0.19 & -0.09 & -0.02 \\
\hline $\mathrm{Na}$ & -0.03 & 0.37 & 0.02 & 0.26 & 0.11 \\
\hline CEC & -0.20 & 0.28 & -0.10 & 0.22 & -0.13 \\
\hline BS & 0.41 & 0.10 & 0.12 & -0.01 & 0.09 \\
\hline AP & 0.21 & 0.19 & 0.01 & 0.22 & 0.14 \\
\hline Clay & -0.01 & -0.20 & 0.25 & 0.24 & 0.59 \\
\hline Silt & -0.14 & -0.03 & 0.45 & 0.22 & -0.37 \\
\hline TOC: $\mathrm{Ca}$ & -0.33 & -0.13 & 0.15 & -0.22 & 0.22 \\
\hline TOC: Clay & -0.10 & 0.33 & 0.10 & -0.28 & -0.47 \\
\hline $\mathrm{CPC}$ & -0.12 & -0.10 & 0.49 & 0.28 & -0.10 \\
\hline ASI & -0.01 & 0.27 & -0.14 & -0.48 & 0.28 \\
\hline Eigen Values & 4.60 & 3.50 & 3.00 & 1.90 & 1.30 \\
\hline Variance (\%) & 25.4 & 19.40 & 16.70 & 10.80 & 7.00 \\
\hline Cumulative Variance (\%) & 25.4 & 44.70 & 61.40 & 72.20 & 79.30 \\
\hline
\end{tabular}

Bold numbers are 'highly weighted' eigenvectors which are within $10 \%$ of the highest values under same PC

The TOC factor loading was (0.35), which is one of the most important attributes and thus, TOC was included

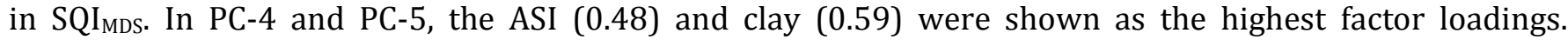
Considering both eigenvectors and correlation matrix (Table 4 and 5), seven weighted soil attributes $\mathrm{Ca}^{2+}$ : $\left(\mathrm{Mg}^{+2}+\mathrm{K}^{+}+\mathrm{Na}^{+}\right), \mathrm{K}^{+}$, TOC: Clay, CPC, TOC, ASI and clay were selected for SQI MDs computation. 


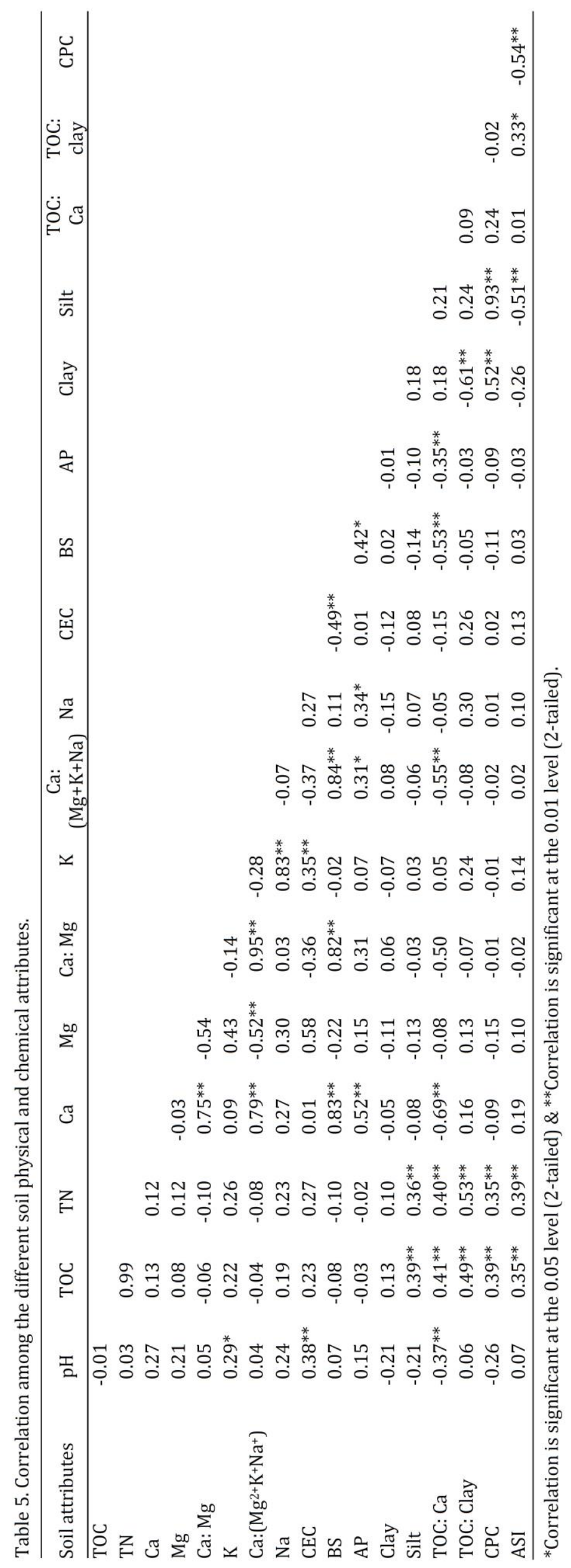


Figure 4 showed that contribution of TOC towards SQIMDS was highest in forest $(25.2 \%)$ followed by fallow (22.7\%), horticultural (20.1\%), agricultural (18.2\%), and degraded lands $(0.15)$. For $\mathrm{K}^{+}$, the highest contribution toward $\mathrm{SQI}_{\mathrm{MDS}}$ was observed under horticulture $(13.1 \%)$ and lowest contribution under forest $(6.6 \%)$ and agriculture (7.4\%). The $\mathrm{Ca}^{2+}:\left(\mathrm{Mg}^{2+}+\mathrm{K}^{+}+\mathrm{Na}^{+}\right)$contributed maximum to $\mathrm{SQI}_{\mathrm{MDS}}$ under agriculture $(22.5 \%)$ compared to minimum under forest (9.3\%). In contrast, clay content exerted highest contribution for $\mathrm{SQI}_{\mathrm{MDS}}$ in degraded land (18.9\%) and minimum under forest (10.7\%). The TOC: clay contribution toward SQI $I_{\text {MDS }}$ was highest under forest (15.4\%) and lowest with agriculture (6.2\%). CPC contribution to SQI $I_{\text {MDS }}$ was maximum under degraded soils (29.3\%) compared to others (17.2 to 20.7\%). However, the ASI contribution for SQI $I_{M D S}$ was highest for forest (12.1\%) and lowest of 8.1\% in degraded soils.

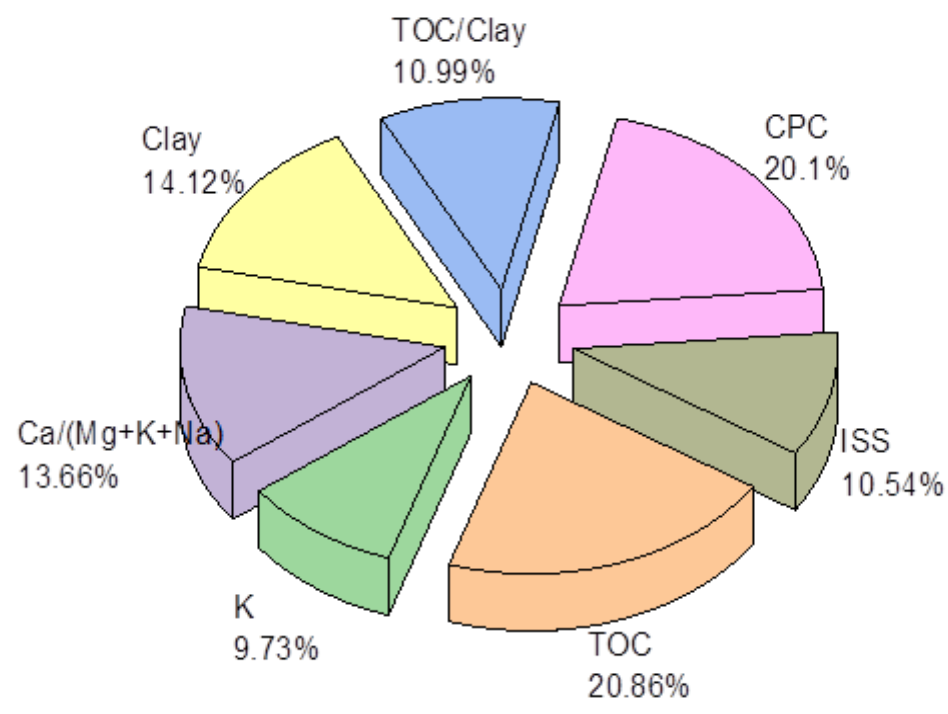

Figure 5. Impact of land-use change on overall contribution of weighted variables.

Results showed that among the selected MDS, the TOC and CPC contributed most $(20.9 \%$ and $21.1 \%)$ followed by clay (14.1\%) and $\mathrm{Ca}^{2+}:\left(\mathrm{Mg}^{2+}+\mathrm{K}^{+}+\mathrm{Na}^{+}\right)(13.7 \%)$, TOC: clay (11\%), and ASI (10.5\%) compared to the lowest by $\mathrm{K}^{+}(9.7 \%)$ to account for variability in SQI IDS (Figure 5). The PCA-based SQI IDS showed a similar pattern, but slightly lower SQ values in response to land use changes (Fig. 2). While the highest SQ was calculated for forest (43.3\%) in SQI $I_{M D S}$, the highest SQI $I_{g}$ calculated for horticulture $(52.1 \%)$. When regressed (Figure 6), the $S Q I_{M D S}$ linearly accounted for $70 \%$ of the variability $\left(R^{2}\right)$ in $S Q I_{g}$, with a significant slope $(\Delta y: \Delta x$ as b) of $0.988(\mathrm{p} \geq 0.0001)$. The intercept (a) of the linear equation $(\mathrm{y}=\mathrm{a}+\mathrm{bx})$ suggested that SQI IDS was slightly underestimated $(6 \pm 3.8 \%)$ to predict SQIg; however, that was statistically non-significant $\left(\mathrm{p} \geq 0.12\right.$ ) between $S Q I_{g}$ and $S Q I_{M D S}$. The t-test showed that there was no significance between $S Q I_{g}$ and $S Q I_{M D S}$ to predict for $\mathrm{SQ}$ in response to land use change.

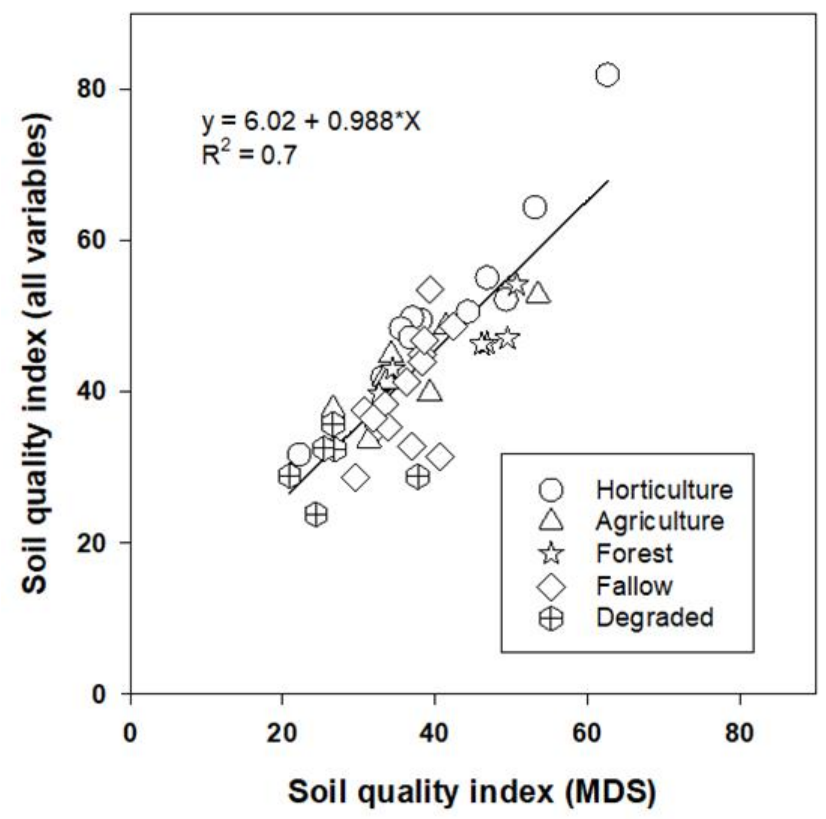

Figure 6. Impact of land-use change on relationship between generalized (SQIg) and minimum dataset based (SQIMDS) soil quality indices. 


\section{Conclusion}

Results showed that the impact of deforestation for land use changes resulted in the deterioration of SQ in Benin. Soil physical and chemical parameters were significantly influenced by land use changes that impacted SQ. Horticulture soils had better SQ than other land uses upon the conversion of natural forest. The PCA identified seven soil attributes including TOC, $\mathrm{Ca}^{2+}:\left(\mathrm{Mg}^{+}+\mathrm{K}^{+}+\mathrm{Na}^{+}\right), \mathrm{K}$, TOC: clay, CPC, ASI and clay for SQI $I_{\text {MDS }}$ computation. The PCA-based SQI ${ }_{\text {MDS }}$ showed a similar pattern, but slightly lower values in SQIg by the

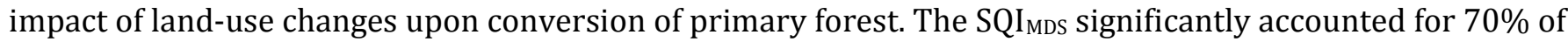
the variability in predicting $S Q I_{g}$. Results showed that there was no significance between $\mathrm{SQI}_{\mathrm{g}}$ and $\mathrm{SQI} \mathrm{IDS}_{\mathrm{M}}$ to predict SQ in response to land-use change. While temporal deforestation for land use change significantly degrading SQ over time, future research is needed to aware the policy makers and farmers for adopting sustainable agricultural practices to improve $S Q$ with enhanced ecosystems services in Benin.

\section{Acknowledgements}

The USDA Norman Borlaug World Food Prize Fellowship provided funding to Drs. Emmanuel Amoakwah (Ghana) and Nataliia Didenko (Ukraine) to conduct their studies on the soil at the Ohio State University, Ohio, USA.

\section{References}

Adaikwu, A.O., Obi, M.E. Ali, A., 2012. Assessment of degradation status of soils in selected areas of Benue State, Southern Guinea Savanna of Nigeria. Nigerian Journal of Soil Science 22: 171-180.

Aziz, I., Mahmood, T., Islam, K.R., 2013. Effect of long-term no-till and conventional tillage practices on soil quality. Soil and Tillage Research 131: 28-35.

Alarima, C.I., Annan-Afful, E., Obalum, S.E., Awotunde, J.M., Masunaga, T., Igwe, C.A., 2020. Comparative assessment of temporal changes in soil degradation under four contrasting land-use options along a tropical toposequence. Land Degradation and Development 31(4): 439-450.

Chandel, S., Hadda, M.S., Mahal, A.K., 2018. Soil quality assessment through minimum data set under different land uses of Submontane Punjab. Communications Soil Science and Plant Analysis 49(6): 658-674.

Chesworth, W., 2008. Encyclopedia of Soil Science, Springer, Dordrecht, The Netherlands, 24p.

Davari, M., Gholami, L., Nabiollahi, K., Homaee, M., Jafari, H.J. 2020. Deforestation and cultivation of sparse forest impacts on soil quality (case study: West Iran, Baneh). Soil and Tillage Research 198: 104504.

Durigan, M.R., Cherubin, M.R., De Camargo, P.B., Ferreira, J.N., Berenguer, E., Gardner, T.A., Barlow, J., dos Santos Dias, C.T., Signor, D., de Oliveira Junior, Cerri, R.C., C.E.P. , 2017. Soil organic matter responses to anthropogenic forest disturbance and land use change in the Eastern Brazilian Amazon. Sustainability 9(3): 379.

Ezeaku, P.I., 2015. Evaluation of agro-ecological approach to soil quality assessment for sustainable land use and management systems. Scientific Research and Essays 10(15): 501-512.

Félix, K.A., Pascal, H., Anastase, A.H., Houinsou, D., Armel, G.S.O., 2015. Farmers' perceptions on soil degradation and their socioeconomic determinants in three watersheds of Southern Benin. Journal of Biology, Agriculture and Healthcare 5(22): 29-39.

Hassink, J., 1997. The capacity of soils to preserve organic C and N by their association with clay and silt particles. Plant and Soil 191: 77-87.

Huddleston, J.H., 1984. Development and use of soil productivity ratings in the United States. Geoderma 32(4): 297-317.

Islam, K.R., Weil, R.R., 2000a. Land use effects on soil quality in a tropical forest ecosystem of Bangladesh. Agriculture, Ecosystem \& Environment 79(1): 9-16.

Islam, K.R., Weil, R.R., 2000b. Soil quality indicator properties in mid-Atlantic soils as influenced by conservation management. Journal of Soil and Water Conservation 55(1): 69-78.

Jackson, M.L., 1958. Soil Chemical Analysis, Prentice Hall Inc. Englewood Cliffs, New Jersey, USA. 498p.

Kalu, S., Koirala, M, Khadka, U.R., Anup, K.C. 2015. Soil quality assessment for different land use in the Panchase area of Western Nepal. International Journal of Environmental Protection 5(1): 38-43.

Kirkby, C.A., Richardson, A.E., Wade, L.J., Batten, G.D., Blanchard, C., Kirkegaard, J.A., 2013. Carbon-nutrient stoichiometry to increase soil carbon sequestration. Soil Biology and Biochemistry 60: 77-86.

Koda, A.D., Dagbenonbakin, G., Assogba, F., Noumavo, P.A., Agbodjatoi, N.A., Assogbai, S., Aguegue, R.M., Adjanohoun, A., Rivera, R., Rivers, R., de la Noval Pons, B.M., Baba-Moussai, L., 2018. Maize (Zea mays l.) response to mycorrhizal fertilization on ferruginous soil of northern Benin. Journal of Experimental Biology and Agricultural Sciences 6(6): 919-928.

Kpera, A., Houngbeme, A.G., Gbaguidi, F.A., Gandaho, S, Gandonou, C.B., 2019. Effect of different doses of the dung of cow, human urine and their combination on water and vitamins contents of pineapple (Ananas comosus (L.) Merr.) in southern Benin. International Journal of Biological and Chemical Sciences 13(4): 2053-2064.

Marzaioli, R., D’Ascoli, R., De Pascale, R.A., Rutigliano, F.A., 2010. Soil quality in a Mediterranean area of Southern Italy as related to different land use types. Applied Soil Ecology 44(3): 205-212. 
Moebius-Clune, B.N., van Es, H.M., Idowu, O.J., Schindelbeck, R.R., Kimetu, J.M., Ngoze, S., Lehmann, J., Kinyangi, J.M., 2011. Long-term soil quality degradation along a cultivation chronosequence in western Kenya. Agriculture, Ecosystem \& Environment 141(1-2): 86-99.

Moges, A., Holden, N.M., 2008. Soil fertility in relation to slope position and agricultural land use: a case study of umbulo catchment in Southern Ethiopia. Environmental Management 42: 753-763.

Moges, A., Dagnachew, M., Yimer, F., 2013. Land use effects on soil quality indicators: A case study of Abo-Wonsho Southern Ethiopia. Applied and Environmental Soil Science Article ID 784989.

Mullar-Harvey, I., Juo, A.S.R., Wilde, A., 1985. Soil organic C, N, S and P after forest clearance in Nigeria: mineralization rates and spatial variability. European Journal of Soil Science 36(4): 585-591.

Murphy, J., Riley, J.P., 1962. A modified single solution method for the determination of phosphate in natural waters. Analytica Chimica Acta 27: 31-36.

Neina, D., 2019. The role of soil pH in plant nutrition and soil remediation. Applied and Environmental Soil Science Article ID 5794869.

Nguemezi, C., Tematio, P., Yemefack, M., Tsozue, D., Silatsa, T.B.F., 2020. Soil quality and soil fertility status in major soil groups at the Tombel area, South-West Cameroon. Heliyon 6(2): e03432.

Nimmo, J.R., Perkins, K.S., 2002. Aggregates stability and size distribution. In: Method of soil analysis Part 4 Physical methods. Soil Science Society of America, Madison, Wisconsin, USA. pp. 317-328.

Obalum, S.E., Buri, M.M., Nwite, J.C., Hermansah, L., Watanabe, Y., Igwe, C.A., Wakatsuki, T., 2012. Soil degradationinduced decline in productivity of sub-Saharan African soils: The prospects of looking downwards the lowlands with the Sawah Ecotechnology. Applied and Environmental Soil Science Article ID 673926.

Onweremadu, E.U., Onyia, V.N., Anikwe, M.A.N., 2007. Carbon and nitrogen distribution in water-stable aggregates under two tillage techniques in Fluvisols of Owerri area, southeastern Nigeria. Soil and Tillage Research 97(2): 195-206.

Ouedraogo, I., Tigabu, M., Savadogo, P., Compaore, H., Odén, P.C., Ouadba, J.M., 2010. Land cover change and its relationship with population dynamics in Burkina Faso, West Africa. Land Degradation \& Development 21(5): 453-462.

Pieri, C.J.M.G., 1992. Fertility of Soils: A Future for Farming in the West African Savannah s.l.: s.n.

Perrin, A., Basset-Mens, C. Huat, J. Yehouess, W., 2015. High environmental risk and low yield of urban tomato gardens in Benin. Agronomy for Sustainable Development 35: 305-315.

Prasad, S.T., Nolte C.H., 1995. Regional characterization of inland valleys agroecosystems in Save, Bante, Bassila, and Parakou regions in south central Republic of Benin. Inland Valleys Characterization Report 1. IITA, Nigeria.

Reicosky, D.C., Forcella, F., 1998. Cover crop and soil quality interactions in agroecosystems. Journal of Soil and Water Conservation 53(3): 224-229.

Rezaei, S.A., Giles, R.J., Andrews, S.S., 2006. A minimum data set for assessing soil quality in rangelands. Geoderma 136(1-2): 229-234.

Rhoades, J.D., 1982. Cation exchange capacity. In: Methods of Soil Analysis Part 2 Chemical and Microbiological Properties. In: Page, A.L., Miller, R.H., Keeney, D.R. (Eds.), 2nd Edition, American Society of Agronomy /Soil Science Society of America. Madison, Wisconsin, U.S.A. pp. 149-158.

Sangare, S.K., Compaore, E, Buerkert, A., Vanclooster, M., Sedego, M.P., Bielders, C.L., 2012. Field-scale analysis of water and nutrient use efficiency for vegetable production in a West African urban agricultural system. Nutrient Cycling in Agroecosystems 92: 207- 224.

Schulte, E.E., Kelling, K.A., 1993. Soil calcium to magnesium ratios - Should you be concerned (A 2986). Cooperative Extension Publications SR-11-93. University of Wixconsin-Extension. Available at [Access date: 11.06.2020]: http://corn.agronomy.wisc.edu/Management/pdfs/a2986.pdf

Sharma, R., Chisti, Y., Banerjee, U.C., 2001. Production, purification, characterization and applications of lipases. Biotechnology Advances 19(8): 627-662.

Schwartz, R.C., Evett, S.R., Unger, P.W., 2003. Soil hydraulic properties of cropland compared with reestablished and native grassland. Geoderma 116(1-2): 47-60.

Sintayehu, D.W., 2018. Impact of climate change on biodiversity and associated key ecosystem services in Africa: a systematic review. Ecosystem Health and Sustainability 4(9): 225-239.

Tellen, V.A., Yerima, B.P.K., 2018. Effects of land use change on soil physicochemical properties in selected areas in the North West region of Cameroon. Environmental Systems Research 7: 3.

Thein, S.J., Graveel, J.G., 1997. Laboratory Manual for Soil Science: Agricultural and Environmental Principles. 7th Edition, McGraw-Hill Higher Education, Dubuque, IA. 218p.

Voundi Nkana, J.C., Demeyer, A., Verloo, M.G., 1998. Chemical effects of wood ash on plant growth in tropical acid soils. Bioresource Technology 63: 251-260.

Wymore, A.W. 1993. Model-Based Systems Engineering. $1^{\text {st }}$ Edition, CRC Press, Boca Raton. USA. 710p.

Yimer, F., Ledin, S., Abdelkadir, A., 2007. Changes in soil organic carbon and total nitrogen contents in three adjacent land use types in the Bale Mountains, south-eastern highlands of Ethiopia. Forest Ecology and Management 242(2-3): 337-342.

Zhang, S.L., Wang, R.J., Yang, X.Y., Sun, B.H., Li, Q.H., 2016. Soil aggregation and aggregating agents as affected by long term contrasting management of an Anthrosol. Scientific Reports 6: 39107. 